DIGITAL COMMONS
@ UNIVERSITY OF SOUTH FLORIDA

Volume 11

Issue 1 Summer 2021

\section{ABO: Interactive Journal for Women in the Arts, 1640-1830}

\title{
The Boy in the Text: Mary Barber, Her Son, and Children's Poetry in Poems on Several Occasions
}

\author{
Chantel M. Lavoie \\ Royal Military College of Canada, chantel.lavoie@rmc.ca
}

Follow this and additional works at: https://digitalcommons.usf.edu/abo

Part of the Educational Methods Commons, Feminist, Gender, and Sexuality Studies Commons, and the Literature in English, British Isles Commons

\section{Recommended Citation}

Lavoie, Chantel M. (2021) "The Boy in the Text: Mary Barber, Her Son, and Children's Poetry in Poems on Several Occasions," ABO: Interactive Journal for Women in the Arts, 1640-1830: Vol.11: Iss.1, Article 2. http://doi.org/10.5038/2157-7129.11.1.1260

Available at: https://digitalcommons.usf.edu/abo/vol11/iss1/2

This Scholarship is brought to you for free and open access by Digital Commons @ University of South Florida. It has been accepted for inclusion in ABO: Interactive Journal for Women in the Arts, 1640-1830 by an authorized administrator of Digital Commons @ University of South Florida. For more information, please contact digitalcommons@usf.edu. 


\title{
The Boy in the Text: Mary Barber, Her Son, and Children's Poetry in Poems on Several Occasions
}

\author{
Abstract \\ The Boy in the Text: Mary Barber, Her Son, and Children's Poetry in Poems on Several Occasions \\ This paper reconsiders the work of Dublin poet Mary Barber, whose collection of poems appeared in \\ $1733 / 34$. There she acknowledges the assistance of Jonathan Swift, and frames her poetry as a \\ pedagogical aid to her children's education-particularly that of her eldest son, Constantine. Barber's \\ relationship with Swift has received much critical attention, as has her focus on her own \\ motherhood-sometimes in critiques that suggest both of these hampered the quality and scope of her \\ work. This paper asks readers to look at her poetry as the children's literature she claimed it was, as well \\ as being crossover literature aimed at more than one generation, published with the hope of the kind of \\ success that Jonathan Swift (and John Gay, and Daniel Defoe) achieved by reaching more than one \\ generation of readers.
}

\section{Keywords}

Mary Barber, Jonathan Swift, Constantine Barber, Poetry, Motherhood, Children's literature

\section{Creative Commons License}

\section{(c) (i) (9)}

This work is licensed under a Creative Commons Attribution-Noncommercial 4.0 License

\section{Cover Page Footnote}

My thanks go to Linda Troost, for her persistent shepherding of the flock. 
Each boist'rous Passion to controul, And early humanize the Soul;

In simple Tales, beside the Fire, The noblest Notions would inspire Mary Barber, "A True Tale"

"She never writes on a Subject with general unconnected Topicks, but always with a Scheme and Method driving to some particular End" (vii)— so wrote Jonathan Swift in 1733 on behalf of fellow Dubliner Mary Barber (c. 16851755). ${ }^{1}$ This praise appears at the beginning of Barber's Poems on Several Occasions. ${ }^{2}$ What we talk about when we talk about Mary Barber always includes - and usually hinges upon - two things: her relationship with Swift, as reflected in his encomium, and her insistently maternal poetic persona. The latter is highlighted in the preface to her book where she anticipates the question "What has the Publick to do with Verses written between a Mother and her Son?" Her answer: "nothing can be of more Use to Society than the taking early Care to form the Minds of Youth" (xxv). Barber justifies her literary presence "with a very different View from any of those which other Attempters in Poetry have proposed to themselves: My Aim being chiefly to form the Minds of my Children" (xvii). Then, this aim having been demonstrated throughout the book, the last poem of the volume criticizes a number of personalities who refused to subscribe to it, among whom is one "Sabina," who thinks Barber "a Fool": "What! — must our Sons be form'd by Rhyme? / A fine Way to employ one's Time!" (277). Evidently the poet, forming her sons, has been engaged in worthy employment. Sabina is wrong.

Nevertheless, due to the occasional and miscellaneous nature of her collection and contributions by other hands, ${ }^{3}$ scholars seldom read Mary Barber's child-centered pieces as children's literature. Instead, her many poems focused upon her eldest son tend to be read as only seeming to be so-as commenting more obliquely and interestingly on limitations placed on women and on her own limitations as a

\footnotetext{
${ }^{1}$ Letter to John Boyle, Earl of Orrery, dated 20 August 1733.

${ }^{2}$ Living for a time in London and Bath, with hopes of moving her family there but encountering significant setbacks due to her health, Barber began collecting subscriptions early in 1730 for the volume of 133 poems (including those by other hands). It appeared in mid-1735, though dated 1734 (Orlando). All quotations from Barber's poems are from this "1734" quarto for subscribers, with page numbers indicated parenthetically.

${ }^{3}$ Such as Elizabeth Singer Rowe's "Verses ... on her drawing the Lord Boyle's Picture" (in Barber 265).
} 
writer. ${ }^{4}$ Bernard Tucker asserts that her poems "gave her the opportunity to assert at least some form of authority. ... As a mother she was able to write at least social criticism rather than the expected saccharine sentiments expected of a (mere) mother writing "verse"" (25). In an intriguing article on Barber and poetic authority, Christopher Fanning has read the poet's copious inclusion of poems by "other hands as a "variety of indirection . . . for each new voice marks an attempt to validate her own authority. Yet, inevitability, the different voices also compromise that attempt" (83). The problem with both the critical attention that praises and the critical attention that finds fault is that, in the first case, we must doubt Barber was "forming [her] sons"; in the latter, we believe her, but then naysaying Sabina was right: Barber wasted her time if she compromised her poetic authority.

The two most insistent "different voices" that make themselves heard at several points throughout Barber's book are those of Dean Swift and of Constantine Barber, her eldest son. Unlike Fanning, I see both her friendship with the man who wrote Gulliver's Travels, to which I will return, and Barber's (re)creation of her son, "Con," as encouragement to think of Mary Barber as a children's poet. Careful rather than radical, Barber would never have requested, as Aphra Behn did, "the Privilege for my Masculine Part the Poet in me." Instead, she suggests that masculine parts in her work come from the traditions of a mentor and from her relationship with her son. Thus, Barber reinvents as well as empowers herself as a poet through tradition rather than innovation. Yet she also importantly reinvents and empowers that son. What if we read these works as Barber claimed in her preface and in their very titles they should be read — as a mother's writing for her children, especially about and for a specific boy? This paper argues that Mary Barber was telling the truth about her role as a mother writing for her children. Further, it argues that accepting Barber's justification opens up wider

\footnotetext{
${ }^{4}$ For example, Barber's “On sending my Son, as a Present, to Dr. Swift, Dean of St. Patrick's, on his Birthday" (71) is read as a celebration of Swift's patriotism with reference to Barber's own humble circumstances because, "as the Wife of a Citizen" (vii), she cannot erect a statue to the Dean. In the second edition of her anthology of children's literature, Demers significantly includes Barber as one of Isaac Watts's near-contemporaries. Demers calls Barber an "observant parent" (78) whose "most charming pieces are monologues she wrote for her son" (90).

${ }^{5}$ Preface to The Luckey Chance (Behn 119). This well-known appeal continues "If I must not, because of my Sex, have this Freedom, but that you will usurp all to yourselves; I lay down my Quill, and you shall hear no more of me." Indeed, any pen-as-penis possibilities are avoided in Barber's Poems on Several Occasions, along with romance, as fellow poet Mary Jones observed: "greatly to the author's honour, that throughout her whole book, I don't remember to have met with one immodest expression; nor, what is more remarkable, a word of that passion which has made so many female poets; I mean love" ("Extract of a Letter from Mrs. Jones to the Hon. Miss Lovelace," in Poems by Eminent Ladies 6). Barber herself asserted, "The Muse I never have debas'd: / My Lays are innocent at least” (283).
} 
possibilities in the genre of early children's literature, as well as considering shared authority between women and children, particularly mothers and sons. It is a common truism that a text constructs the child it purports to address. In Barber's Poems on Several Occasions, the text also respectfully addresses the child it purports to construct.

The mother-poet in Poems on Several Occasions obviously directs our attention to those children who made her a mother (and, by her own syllogism, a poet). Barber bore at least nine children, four of whom survived to adulthood. ${ }^{6}$ Some eighteen of the poems are explicitly written for her eldest son Constantine (c. 1713-83), for example, "Written for my Son in his Sickness, to one of his Schoolfellows," "Written for my Son, in a Bible which was presented to him," and "Written for my Son, and spoken by him, at a public Examination for Victors." Other titles include similar filial references, as in "To the Right Honourable John Barber . . on committing one of my Sons to his Care."

In each of these poems, it is through a son that the poet displaces and thereby enacts power and authority. Fanning reads Barber "construct[ing] a female poetic identity through indirection: the use of other voices by 'ghost writing' for others, the creating of satiric personae, quotation, and the inclusion of others' writing in her volume. The necessary paradox of this indirect technique is that the identity thus created requires a degree of self-effacement which obscures authority" (82). With Barber's "quotation of self" as the mother in so many of her works comes an ambiguous "language of authority" (83). I identify ambiguous language in the poet's work as well, but I argue that this ambiguity itself invites us to consider much of Barber's verse as literature for children. In the piece "Written for my Son, to Mr. Barry; occasion'd by the foregoing Verses" (the foregoing verses amusingly accusing the boy of pretending his mother's verses are his own), the "Son" explains "My Mother told me many a Time, / That Double-dealing was a Crime" (85). Given that the verses are "for my Son," the double-dealing is selfevident, out in the open. It is also how the poet deals - doubly-with two generations as readers.

The ways in which the male child is imagined and embedded in Mary Barber's book, along with how the mother and son speak for and through each other, therefore, have yet to be sufficiently engaged by scholars. In contrast to Tucker's

\footnotetext{
${ }^{6}$ When Barber's Poems was published, Constantine had just received his bachelor's degree at Trinity College, Dublin, while another son, Rupert (1719-72), was apprenticed to become a painter of miniatures at Bath. Barber's daughter Mira (sometimes Myra, b. 1717) was described by family friends as "drooping" and destined to be a spinster, and a youngest son, Lucius, was also at home (Delany 2: 316).
} 
gratitude for the little authority the role of mother afforded Barber, Margaret Ezell argues that, because the eighteenth-century "vocabulary of critical praise is masculine. ... [f] or a woman writer, therefore, a type of androgyny was the literary goal" (72-73). Ezell concludes that Jonathan Swift appreciated "Barber's poetry [as] rational, didactic, and well organized and . . not a reflection of her gender, social rank, or domestic activities. It is, in fact, entirely distinct from those factors governing her private life and as such praiseworthy" (73). However, parts of that private life are so publicized in the verse that to ignore gender, social rank, and, most of all, the domestic role of motherhood is an inadequate response to Barber. Unlike Ezell, A. C. Elias stresses that Mary Barber was "a poet of middleclass motherhood responding to and writing about the children she raised, the education she gave them, the household she ran, the people she met, the places she went, and the events she witnessed" ("Editing" 146-47). Clearly, then, minor poet Barber remains open to interpretive debate. If we find it sometimes irksome to read that the verses from "when [her] Son was a Schoolboy" were "the best Apology a Woman could make for writing at all" (xxv-xxvi), we will ignore the importance of the new thing that she is doing in giving those verses their place in her collection. In addressing the viewpoint of her son, the mother-poet speaks to what women and boys have in common, including the important fact that neither of them are men.

Boys, however, will become men so, while the boy who is reflected and instructed in Barber's text is an important character therein, the characters of the men in her life who contributed to the publication of her collection (and to the financial need for her to publish) are part of the book as well. One of these, Mary Barber's husband, is conspicuous by his virtual absence; two others-Jonathan Swift and John Gay - contribute to my argument for considering Poems on Several Occasions as an early exercise in children's literature.

\section{The Men: The "good natur'd husband"}

The father of Mary Barber's children, Rupert Barber, Sr. (d. 1777?), was a largely unsuccessful woolen merchant (or tailor, as The Orlando Project states) who had given up his shop by 1732 and was acting as a property agent for Dr. Patrick Delany (Orlando; Budd 214n31). Publicly, Jonathan Swift wrote guardedly of him: "I am assured, that no Woman was ever more useful to her Husband in the Way of Business"; privately, he listed Mr. Barber among the "ungrateful" people he had known. ${ }^{7}$ Other evidence suggests that Rupert was singularly inept at supporting his family despite attempts on his behalf by friends of his wife.

\footnotetext{
7 "Dedicatory letter to John Boyle" (in Barber vii) and "Swift's Friends Classified by their Character" (in Swift's Correspondence 5: 270).
} 
Memoirist and bluestocking Mary Delany wrote in 1755 (the year Mary Barber died) that "Old Mr. Barber is alive, drinks his claret, smokes his pipe, and cares not a pin for any of his family" (3: 327). Over twenty years earlier, Delany's husband referred to Mrs. Barber's four children as "excellently educated, perfectly well-disposed, and utterly unprovided for." 8

Certainly, the story behind the book is both that Mary wrote chiefly to educate her children and that she was in financial straits. ${ }^{9}$ Sarah Prescott argues that, in the period from 1690 to 1740 , the "view that poetry was non-commercial, amateur and part of a woman's usual accomplishments, helps to explain why those women writers who gained the most prestige and recognition from the male literary establishment were primarily poets, not novelists" (30). Whereas this theory regarding poetry and amateurishness suits Barber, it also does not. Frankly - and she was frank about it-she needed the money that subscription publication was meant to bring in. ${ }^{10}$ Poems on Several Occasions was a brainchild conceived first to educate, then to support financially these four children.

\section{The Men: Dean Swift}

The person who husbanded these poems into publication was Jonathan Swift, chiefly by soliciting such subscriptions for the book. It has often been remarked that, for a self-avowed misanthropist, Swift had a lot of good friends. Nor did Swift, while despising humanity, find it in his heart only to "love John, Peter, Thomas, and so forth"; ${ }^{11}$ there was also the occasional Mary. Harold Love outlines the complicated difficulty of assigning Barber authorship for all of her work, given the consulting she did with Swift and other Dublin friends (46). ${ }^{12}$

\footnotetext{
${ }^{8}$ Patrick Delany to Charlotte Clayton, 27 February [1731] (in Delany 1: 322).

${ }^{9}$ Budd shows that Barber's collection "has the longest list of subscribers [918 names] known in the period, and a distinguished list too, [but] proceeds from Mary Barber's poetry did not materially assist her in coping with her financial problems" (209-10) due to subscribers not collecting or paying for their copies (213). Copies were apparently remaindered or sold for their paper: Laetitia Pilkington, no longer a friend to Barber, claimed the poems "might, at this Day, be seen in the Cheesemongers, Chandlers, Pastry-cooks, and Second-hand Booksellers Shops" (1: 283); also see Elias, "Editing."

${ }^{10}$ In 1730, laboring-class poet Stephen Duck achieved fame and modest fortune when he was favored by Queen Caroline. Since Caroline is often mentioned in Barber's poems, we can surmise that she might have had hopes for recognition from royal circles as well and saw in "Duck's career a trajectory for her own" (Stewart 162); see also Budd 206-207.

11 Jonathan Swift to Alexander Pope, 29 September 1725 (in Swift's Correspondence 3: 103).

${ }^{12}$ Mrs. Barber participated in a regular Dublin gathering that Dr. Delany referred to as a Senatus Consultum. Pilkington, in whose Memoirs her former friend is none too kindly treated, wrote that,
} 
Louise Barnett does not exaggerate in saying, "that Swift was a congenial influence appears everywhere in Barber's poetry" (89). Much of Barber's mostly light verse is written in tetrameter couplets, a verse form Margaret Anne Doody identifies as influenced by Swift, as might also be some of her playfulness in constructing different poetic voices.

More directly, in the final poem in the collection, which dwells upon the burden of subscription publication, Barber could smugly put this couplet in the mouth of one of her critics: "She may succeed among the Men; / They tell me, SWIFT subscribes for Ten" (276). ${ }^{13}$ The couplet is a reminder, given other criticism mentioned in the same poem about "employ[ing] one's Time!" with forming "Sons ... by Rhyme" (277), that well-educated boys become men who respect women, so that to "succeed among the Men" involves succeeding with the boys. As for men, Swift is a character in his own right in Poems on Several Occasions, and she invokes his name throughout. In Barber's succinct "An Epigram on the Battle of the Books," for example, the Dean is both authorial and authoritative: "SWIFT for the Antients has argu'd so well, / 'Tis apparent from thence, that the Moderns excel" (164). Through him, too, she met (although with not much success) some of those moderns-Alexander Pope and John Gay. Certainly, Swift's collaborative spirit on many levels - personal encouragement, solicitation of subscription, and exemplar of a literary career - all had an impact on Mary Barber. ${ }^{14}$

Fanning links the "disregard" (81) he identifies in terms of critical attention to Barber's collection with "her appearance in twentieth-century scholarship as a footnote to the life and works of Jonathan Swift" (82). This is a paradoxical critical lament since, as he notes, Pope, Gay, Arbuthnot, Walpole, and others subscribed to her book because of Swift. With good reason, Fanning argues most critical mentions of Barber to date "do little to dispel Swift's shade" (95n6).

\footnotetext{
"dull as they were," Barber's poems "certainly would have been much worse" had it not been for the collaborative correcting of her "undigested Materials" by the Senatus (283).

${ }^{13}$ Swift is, indeed, put down for ten copies in the subscriber list (Barber xli).

14 "The tireless efforts of the distinguished 'misanthropist' on her behalf among his aristocratic and literary friends in England can be appreciated only by reading his many letters on the subject" (Lonsdale xxvi). The scope of this paper does not allow for a study of how Barber's friendship with and great kindness received from Swift might problematize our reading of his own misogynistic writings. Salvaggio (among others) has argued that, in his poems and in Gulliver, the other sex "is either the mother he seeks and the lover he fears, or she epitomizes a repository of filth and pleasure which this Christian moralist shuns" (418). In Swift's defense, Doody argues "for every female voice raised against Swift there are several to speak for him" (72): Swift "proves good to know" (91). The regard between the Dean and Mrs. Barber was certainly mutual. Folkenflik notes that Mary Barber "was one of the few nonclergy given a memorial present in [Swift's] will dated May 1740" (124).
} 
Considering her work as children's literature offers another, enlightening connection to Swift with regard to how Barber might have looked to his example, not only for how to write her couplets or how to attain subscribers, but also for how to appeal to a wider audience.

\section{Small World: Children's literature circa 1735}

In Women and the Shaping of the Nation's Young, Mary Hilton explores how the expansion of print culture and the new money economy of the mid-eighteenth century broke down boundaries between genres: "Varying social and literary practices ... now meant that genre offered a fluid intellectual resource that writers could begin to use creatively. In fact textual heterogeneity at mid-century was bewildering, as enterprising publishers such as John Newbery and Samuel Richardson encouraged new literary approaches" (40). Mary Barber's collection (which was printed by Richardson) appeared before - but not that much beforethe rise of children's literature that is identified with the 1740s because of the work of Newbery and Mary Cooper. Yet, prior to this, as Harvey Darton has noted, in the first part of the eighteenth century, "three books appeared which made a deep mark in children's literature. ... They were Isaac Watts's Divine Songs Attempted in Easy Language for the Use of Children (1715), Defoe's Robinson Crusoe (1719), and Swift's Gulliver's Travels (1726)" (106). All three have been extensively analyzed regarding their popularity with young readers. ${ }^{15}$ As Darton points out, both Crusoe and Gulliver "got into summary chapbook versions very early. The novel-reading habit reached the nursery almost before grown-ups had acquired it" (107-108). Evidence of the success and influence of these three books is profuse; for Mary Barber, protégé of Swift, Gulliver's success as a crossover text might have had a greater impact than has been considered.

Gulliver had scarcely appeared in November 1726 when Gay wrote to Swift, "About ten days ago a Book was publish'd here of the Travels of one Gulliver, which hath been the conversation of the whole town ever since. ... From the highest to the lowest it is universally read, from the Cabinet-council to the Nursery. . . a and the whole town, men, women, and children are quite full of it." 16 Gay's complimentary letter indicates that there is nothing wrong with having such a wide readership and signals that appealing to all generations and both sexes is praiseworthy. I am not implying that Swift wrote his complex satire for children but rather that the appeal and adaptations of Gulliver's Travels for children was an observable phenomenon. The potential for such commingling of genres and

\footnotetext{
${ }^{15}$ See for example Andrew O’Malley.

${ }^{16}$ John Gay to Jonathan Swift, 17 November 1726 (in Swift's Correspondence 3: 182).
} 
audiences also appears in Barber's poetry collection (where, as Tucker has observed, the preliminary letter of recommendation and authorial dedication resemble the preliminary material of Gulliver (11)).

As Poems on Several Occasions speaks loudly to the influence of Swift the man in Mary Barber's life, her collection also reflects the influence of that man's authorial style. Doody posits that Barber's frequent "presentation of the self as a comic and sometimes awkward figure" was "perhaps learned" from Swift (74). ${ }^{17}$ Doody focuses on Swift's verse when she calls him "the model for ironic selfrepresentation, for the double-edged view of the hard social perceptions forced on the helpless self' (74); however, the Dean's satiric travel narrative offered both a double-edged view and (at least) a double-edged genre and, as noted above, it appealed to a multigenerational audience. We are not always meant to take Mary Barber's poetic speaker seriously, a strategy that the author of Gulliver had carried over from his own poetry to his prose. Given these echoes as well as Barber's friendship with Swift and tutelage at his deanery, it is worth considering Barber's poems relating to children's lives as encouraging the kind of intergenerational readership her mentor achieved with Gulliver.

Nor was Swift's the only example before her as Barber organized her poems and the friends of friends to subscribe to them. A year after praising Swift's appeal "from the Cabinet-council to the Nursery," Gay himself tried to please readers from the throne to the nursery by dedicating his political and satirical Fables to six-year-old Prince William, later to become the Duke of Cumberland. In 1725, Mary Barber published a poem that is both a tribute to and a complaint on behalf of Gay: "A Tale Being an Addition to Mr. Gay's Fables" appears slightly altered and retitled as "A True Tale" in her 1735 Poems. The poem begins with her reason for writing, but it soon slips into a familiar sharing of voices-mother and son:

A MOTHER, who vast Pleasure finds

In modelling her Childrens Minds;

With whom, in exquisite Delight,

She passes many a Winter Night;

Mingles in ev'ry Play, to find

What Byass Nature gave the Mind;

Resolving thence to take her Aim,

To guide them to the Realms of Fame;

And wisely make those Realms their Way,

\footnotetext{
${ }^{17}$ Staves demonstrates Swift's poetry proved a useful model for Barber: "his colloquially rhymed tetrameter couplets were unpretentious, suited to a less-educated woman poet, like Barber, who intended to stay in her social position as a tradesman's wife" (201).
} 
To Regions of eternal Day. ... (7)

Gay's Fables are then highly praised when the mother's "fav'rite Son the Volume seiz'd" (10). In the poem, Constantine Barber acts as a stand-in for his mother as the boy is dismayed that Gay has not received recompense from the queen for the fables. The mother has obviously informed the boy of this apparent injustice. The son then asks his mother what she would do for Gay if she were queen, so the poem ends with her voice: "WHAT I'd bestow, says she, my Dear? / At least, $a$ thousand Pounds a Year" (12). ${ }^{18}$ Hence, the piece both praises Gay's accomplishment and argues that material and eternal rewards are linked — or they should be, since Gay, the writer who helps the mother prepare children for "Regions of eternal Day" (7), ought to be richly rewarded on earth.

In her praise of Gay, Barber is writing about something she interprets as children's literature (given that she is reading it to her own son). It is therefore debatable whether her own poem belongs to that genre, yet the genre was evolving. In The Child Reader, Matthew Grenby argues that poems like this one concerning Barber's son as well as her use of scripture stories, references to Joseph Addison, Pope, and Gay's Fables rather than "texts designed especially for the young [reflect] a reluctance to admit to 'childish reading"” (94). Grenby's concern here is with the absence of genuine recommendations by Barber of texts "published specifically for children" although he does give weight to the possibility that Barber's 1728 poem, “A Tale, Being an Addition to Mr. Gay’s Fables," is, in part, one such text. Annabel Patterson and Laura Brown have demonstrated how sophisticated and "adult" are the fables of John Gay (like those of Aesop and Jean de la Fontaine). ${ }^{19}$ Frequently politically nuanced statements, fables are also often adult and brutal (though Barber's are not). However, fables were considered not only appropriate, but indeed ideal for children in the eighteenth century: John Locke, too, had recommended the genre (Aesop) for

\footnotetext{
${ }^{18}$ Another piece that references Gay, "To Robert Barber . . . on his attending, whilst his Son repeated GAY's Fable of the Hare and Many Friends," begins with a link between "GAY's unhappy Fate" and "his faithless Friends" (Barber 267). This complaint about merit unrewarded by royalty and general ingratitude for the arts is a recurring one in Barber's work.

${ }^{19}$ See Patterson and Brown. Four other non-human fables appear in Barber's Poems dealing with themes of gratitude and changing fortune, aimed more at adults than children. Another friend of Swift's, Anne Finch, Countess of Winchelsea, had included, to loud acclaim, a number of translated and original fables in her Miscellany Poems on Several Occasions in 1713; Finch was proving a good model for many women who dared to publish (as the similarity of Barber's title to Finch's suggests). The only occasional collection by one woman between these two was Mary Masters's in 1733.
} 
children's instruction. ${ }^{20}$ Gay's work appeared in over 350 editions and, most importantly, "quickly became a stable text in school libraries" (Demers 88). Given the fluid nature of the fabulist's work in terms of genre and audience, why should Mary Barber's not merit the same openness to generic interpretation?

Since Gay courted all audiences and Swift's Gulliver appealed to a wide range of readers, surely Barber's strategy of writing a text that slips between childhood and adulthood deserves further investigation rather than dismissal as only a selfobscuring mask of motherhood. Swift himself might have hinted as much in that dedicatory letter to Orrery, vouching that Mrs. Barber "never writes on a Subject with general unconnected Topicks, but always with a Scheme and Method driving to some particular End" (vii). Barber, who travelled to England to further her book, wrote with gratitude of her supporters in her preface: "It is my Happiness to have received Encouragement from many in both Kingdoms, to whom it is an Honour to be indebted" (xxiv). I am not arguing that she was particularly successful - either monetarily or consistently artistically - but I do believe that she was consciously attempting to be received in the kingdoms of adult readers and children as well as in the kingdoms of Ireland and Great Britain.

\section{The Boy: Written "For my son"}

In addition to poems with passing references to Con Barber, eighteen poems in Barber's collection are, as noted above, partly titled "For my son." Sometimes, the word for means "on behalf of," as in "Written for my Son, and Spoken by Him, At a Public Examination." Sometimes, for is really "for his eyes," as in "Written for My Son, in a Bible which was presented to him." Usually, it is both - on his behalf, and also for him to read and approve. In several pieces, Con's voice is used to address a schoolfellow, some of the verses referencing his mother. ${ }^{21}$

The account of Mary Barber in Orlando refers to the poems written as if by Constantine Barber as creating "ironic distance between poet and immature speaker," yet there is an ironic proximity between the two voices here, too. Doody suggests that Barber "seizes upon the one kind of authority she certainly has that the world might acknowledge: her maternal authority. This strangely allows her to

\footnotetext{
${ }^{20}$ Regarding eighteenth-century adaptations of Aesop for children, see Pickering 192.

${ }^{21}$ A search among Barber's poems for the phrase "my son" yields twenty-seven appearances, including one spoken by a desperate widow who is watching her children starve because the pension of her deceased husband - an officer - has not been granted. That poem appeared first in a 1731 miscellany, The Flower-Piece, edited in Dublin by Mathew Concanen (Lonsdale 522n84).
} 
access the male world and a male voice" (73) in instances when we hear from "the schoolboy - apologizing for homework not done, avoiding the rod, expressing gratitude for a play-day, or discomfort in new clothes" (Fanning 83). I agree with Doody's argument about access, but I think it important not to lose sight of the fact that this "male world and . . . male voice" are more specifically a boy's world and a boy's voice. Throughout the collection, Barber subtly but pervasively reminds her reader that there is a difference between a boy's world and a man's. She includes both but, overall, privileges the former.

This distinction between these two worlds is nowhere more evident than in Barber's most-anthologized poem, "Written for my Son, and Spoken by him at his first putting on Breeches." It begins by apparently setting the wishes of boys against those of their mothers:

WHAT is it our Mammas bewitches, To plague us little Boys with Breeches?

To Tyrant Custom we must yield, Whilst vanquish'd Reason flies the field. (13)

The boy, who would have worn a frock in early childhood, is likely about seven years old, the age at which breeching usually occurred. ${ }^{22}$ In addition to the breeches, he also complains of shoes, cuffs, hat-bands, and cravats, unnatural contrivances that have come about due to "Custom. ... The only Monarch All obey" (15-16). Fanning observes that "[A]lthough Doody ... and Tucker . . . see this poem as a unique satire against adult male clothing, and some of the articles (such as hatbands or cravats) are specifically male, the complaints are equally applicable to female concerns" (87-88): the "political and military imagery ... provides the framework for a critique of the restrictions men impose upon women in the indirect terms of a clothing metaphor" (87). Certainly, Fanning's point about the sartorial connection between women and children is valid. Yet I believe that the boy qua boy in breeches is far more important here than boy's

constrictions as mirroring woman's constrictions. Just when the child is presumed to reach the age of reason, custom overrides it. The sartorial custom against which the child rails - even as it makes him more adult - actually defies reason and "Delights to make us act like Fools" (16). Sartorial discomfort, like other manifestations of "Tyrant Custom," is indeed shared by women and boys, but Barber's poem most strongly suggests a kind of violence particular to the custom of breeching, for which mothers are blamed but also for which, clearly, this

${ }^{22}$ I consider this sartorial/cultural practice more widely in my essay "Tristram Shandy, Boyhood, and Breeching." 
mother has sympathy. This stage of becoming a man is therefore to be grieved for a little.

Further into the poem, the boy laments "Dress, that should prolong our Date, / Is made to hasten on our Fate" and that humans are therefore, "more plagu'd than other Creatures!" (14). As Fanning points out, the tenor and content of these lines are "above a child. The poem exceeds the limitations of the mouthpiece which allows the poem to be voiced, thus necessarily drawing attention to the female poet's disguised authority" (88). Surely, though, all the good children of eighteenth-century literature and those who have populated the genre sinceespecially the clever ones - tend to speak "above" themselves. There are within Barber's work many references too specific for a general child-reader to understand, but many child-centered texts - about Alice, Peter Pan, Winnie the Pooh, to name a few-have begun with one reader, the ideal precocious child, in perfect sympathy with the author. ${ }^{23}$ More specifically, as Patricia Demers explains, in taking on her son's voice, the "mock serious tone. . . barely conceals Barber's wit" (90). Barber knowingly signals both that her son is no ordinary child and that his mother is no ordinary mother.

It is this sympathy for the son in Poems on Several Occasions that opens the text as literature not just about but also for children, especially boys. Eric Tribunella argues "Boyhood has always constituted a kind of problem. To be a boy means to be a flawed, inchoate, or incomplete man. . . . We can read in children's literature the morally and socially subversive high jinks of boyhood, the sense of boyhood as a time of constraint and confinement, and the themes of escape and empowerment that often permeate books about boys" (22). In significant ways, therefore, boys are liminal. In Barber's breeching poem and in her collection as a whole, although constraint and confinement appear (and although the first line of the poem blames the "Mammas" for sartorial confinement), I think that the status of "incomplete man" is both sympathized with and celebrated.

Another poem in which Barber sympathetically ventriloquizes Con praises the considerable influence of John Locke on ideas about education. In the piece "Written for my son, and spoken by him in School, Upon his Master's first bringing in a Rod," Locke is the "Sage . . Who taught to play us into Learning, /

${ }^{23}$ Barber herself evidences pride at her son's positive response to Gay's Fables: he "Made such Reflections ev'ry Page, / The Mother thought above his Age" (10). Pickering points out "[Anna Letitia] Barbauld's graduated Lessons [1787, 1789] made publishers more aware of the differences between the mental capacities of children of different ages" (192). 
By 'graving Letters on the Dice" (36-37). ${ }^{24}$ The lines that follow, in which the boy's schoolmaster is urged to embrace Locke's teachings and, as a result, win for the school "all the Elder Brothers, / And be the Darling of the Mothers" (37), speaks to the duality, not only of the poet's voice but also of the intended audience of Barber's own ideas. The poem opposing corporal punishment must of course be aimed at those who enforce it - adults — but because it is voiced by a child, it strongly suggests that the interests of schoolboys and mothers are the same.

In Some Thoughts Concerning Education, Locke called the rod "the usual, lazy, and short Way by Chastisement ... the only Instrument of Government that Tutors generally know, or ever think of" (§47). Samuel F. Pickering has demonstrated how profoundly the children's literature produced in the eighteenth century was a by-product of Locke's theories; by the time Barber was writing, this Lockean chastisement was au courant and the rod debatably "the most unfit of any to be used in Education" ( $(47)$. That the master-and-rod poem follows soon after the lament about moving from frock to breeches also creates an instance of narrative in the book of poems as innocence moves further into experience, and this narrativity honors the child. Furthermore, Barber's questioning of pedagogical methods - even when the voice is meant to be her son's - reinforces the pedagogical agenda she explains in the preface to her book: "I imagin'd that Precepts convey'd in Verse would be easier remember'd, and that their being obliged to repeat them in School, would greatly contribute, not only to fix them more firmly in the Mind, but to give early a proper and graceful Manner of speaking" (xvii-xviii). Compare that to Isaac Watts's preface to Divine Songs (1715): "There is something so amusing and entertaining in rhymes and metre that will incline children to make this part of their business a diversion" (qtd. in Demers 77). Whereas Barber's is a more secular approach, she, too, is clearly thinking about writing for children - as "Con" explains both in and about his mother's words: "my Mamma . . . loves to make / Reflections, for her Children's Sake" (43).

"By creating poetic personae or writing for other speakers," Fanning argues, "Mary Barber creates a division between 'actor' (or speaker) and 'author' to obscure the question of agency" (83). As a case study in writing early children's poetry, Barber demonstrates nuanced ways in which much "women's writing" was also often children's literature, which itself reminds us that agency is a

\footnotetext{
${ }^{24}$ The poet's pedagogical interests are also evident in "A True Tale," where the mother delights in showing "the Story on the Tiles" (8).
} 
complicated issue for both women and children." ${ }^{25}$ As such, her work offers an intriguing cross-pollination between the concerns of women who are mothers and boys who are sons that speaks to a strong bond between these two groups of nonmen. I suggest an empowerment in this strategy not so different from how we might read the voice of Swift in Gulliver, where actor (or speaker) and author are divided and yet (still) obscured. For instance, Barber's playful poem on the tyranny of fashion (including shoes "With narrow Toes, and Heels like Pegs, / To help to make us break our Legs" [14)] together with her condemnation of corporal punishment at school raise questions about power and barbarity in her own civilization on a childhood-as-Lilliput level. ${ }^{26}$

This image of son writ large impresses itself on Barber's text. While Constantine Barber is the best-beloved son in the book, his mother's other sons are not absent. In "To a Lady, who invited the Author into the Country," Barber compares the peace of the landscape which that lady surveys with her own urban hardships, for which there is only the consolation of motherhood: "I'm sick of Smells, and Dirty Streets, / Stifled with Smoke, and stunn'd with Noise / Of ev'ry thing-but my own Boys" (134). Here, a particular gift to the reader is that the conventional rhyming of boys with noise is not to align the two, but to contrast them. In another, sent "To the Right Honourable John Barber, Esq; Lord Mayor of London [no relation] on committing one of my Sons to his Care" (225-26), the fond mother "imagines young Lucius (or possibly Rupert) as a wild child captured in Hibernia who has ... the qualities to become a businessman, or perhaps Lord Mayor" (Folkenflik 124). By contrast, the only poem written on behalf of Barber's daughter concerns her mother not allowing the girl to wear a crimson velvet cap given to her by a lady, for fear it will seem affectation. Mira (the daughter) explains that her mother makes an exception about this cap for one reason, namely, the boy in the text: "THIS Day, to please my Brother Con / She let me put your Present on" (56).

Constantine, the "favourite son" as he is called in the poem on Gay's Fables, is obviously the central character of the poetic collection. Aligned thus in one way

\footnotetext{
25 "Some [forms], like letter-writing or children's writing, have been practised particularly by women, recognized for centuries as areas of female specialization" (Blain, Clements, and Grundy viii). Despite recognition and fine work by such scholars as Myers, much writing by women from earlier in the eighteenth century has not been explored in this light. That being said, Perry Nodelman complains about what he sees as a levelling impulse (and exclusion of men), in which "Children's literature as a genre might be a sort of feminine literature which shares generic characteristics with writing for adults by women" (32).

${ }^{26}$ Gamache points out that Barber's "focus on absurd clothing practices" also "recalls Gulliver's observations during this voyage to Lilliput" (16).
} 
or another with Swift, Gay, and Locke through their varied roles in his mother's book, Con's voice is woven together with theirs and with hers. Mary Barber's son gives his mother license to be playful. The writing of these poems, however, has not been a frivolous exercise. Rather, the persistent message throughout the Poems culminates in Con's own adult voice praising his mother (discussed below). The boy in the text, therefore, answers the vacuous Sabina: evidently, to have sons "form'd by rhyme" is indeed "A fine way to employ one's time!"

The result of the many voices in Barber's book, which Fanning reads as diminishing the poet's authority, I see as exercising dual-gendered and crossgenerational authority. This authority is evident in the interesting beginning of her piece addressed to a misogynistic "Rev. Mr. C-" whom Barber wants to put in his place. ${ }^{27}$ The first couplet is "'TIs Time to conclude; for I make it a Rule, / To leave off all Writing, when Con. comes from School" (58). However, she does not leave off writing; instead, she describes the kind of wife her son should choose. The ideal helpmate is to be

a Woman of Wisdom, as well as good Breeding, With a Turn, at least no Aversion, to Reading: In the Care of her Person, exact and refin'd; Yet still, let her principal Care be her Mind. (61)

This is certainly part of her retort to the Rev. Mr. C - who, we learn, "thinks it a Crime in a Woman to read" (58), but it is at the same time serious advice to her son. She wants him to be different, superior, and "blest in [his] Children and Wife" (62). In a word: happy. She does not want her Constantine to turn into yet another misogynistic Mr. C- This poem also echoes Barber's praise of Lord Orrery in her dedication: "A good Son, and a good Husband, are Characters that include whatever is most amiable in human Nature; at least, if Mothers and Wives, may be allowed for Judges" (xii).

\section{The boy "unshipwreck'd, thro' the Storm of Youth": Constantine writes himself}

It is not surprising this eighteenth-century woman concentrates on her "favourite son" and "heir." Recall that five of her children had died, and that such loss was

\footnotetext{
27 This poem contains one of only two references to Barber's husband in the book. Here, Barber imagines what Mr. C - might be thinking: "I pity poor Barber, his Wife's so romantick: / A Letter in Rhyme!-Why, the Woman is frantick!" (58).
} 
common. ${ }^{28}$ The poet's experience of motherhood is intimately intertwined with the happiness of this child in particular. Barber's collection celebrates not just the boy, but also the boy who has lived to manhood because near the end of her volume appear five poems written by Constantine himself as an adult. Barber introduces them "as Instances of that Filial Piety. . . in some measure the Consequence of the Care it hath amply rewarded" (xxvi). The word care appears repeatedly Barber's book; this "Care" is part of the argument she is making for her worth as a mother, a poet, and-however we might read this now-a woman.

The first poem by the older Con, "A Letter sent to Mrs. Barber, at Tunbridge Wells," is postscripted "Dublin, August 28, 1731. the Author's Birth-day. Constantine Barber." Here the son's gratitude is glowing:

Her Guardian Care did all my Griefs assuage, Those sure Attendants of an Infant Age! By her conducted to the Light of Truth, I sail, unshipwreck'd, thro' the Storm of Youth. (248)

Constantine was turning seventeen on this date, with his mother at the English spa town trying to recover her health and attain subscriptions for her poems. He addresses her as "Thou best of Mothers, and thou best of Friends!" (249). Four more poems by Con follow, all from 1733. On New Year's Day of that year, the son hopes for his mother that "the Fates thy vital Thread prolong, / And make thy Life immortal as thy Song" (254). Here, poetic hyperbole, umbilical cords, and apron strings are intertwined, yet what stands out cumulatively in the book is the mutual admiration and usefulness of the mother-son relationship. The appearance of the grown son's voice near the end of the book also contributes to the element of linear narrative that runs through the largely miscellaneous collection.

\section{Behind every great man}

In a way, Mary Barber has two voices in her collection: her own and that which she creates on behalf of her son as a boy. That son also has two voices: his own and the one his mother writes for him as a boy. Placed before the encomiastic pieces written by young man Con is a teasing poem about the boy Con, accusing him of borrowing his mother's words. In "To Mr. Rose ... Written by the Reverend Dr. T-," the son is accused of pretending authorship for poems that "ne'er could spring from his poor Baby Head" (83); rather, "They are his

\footnotetext{
${ }^{28}$ We cannot know how many pregnancies Barber might have had. Two poems by Barber consoling friends on the loss of a child appear in her book.
} 
Mother's Verses, not his own" (83). This theme recurs. In "Upon my Son's speaking Latin in School to less Advantage than English"-written by yet another hand-young Con is teased with the assertion that his schoolboy "Verse, so much admir'd, / By her superior Genius was inspir'd" because "The Muse, thy Mother, only speaks in thee" (87). The author of this piece is Constantia Grierson, Barber's recently deceased friend. ${ }^{29}$ Susan Staves notes approvingly that these poems have "reversed the standard situation in which the woman's writing is said not to be her own, the situation complained of, for instance, in Ann Killigrew's 'Upon the Saying That My Verses Were Made by Another'” (203).

To me, this reading can be pushed further with the familial element at work as it connects women and children through literature. The poetry of the mother speaking "in" rather than "for" her son is touching. She is still working to form him. Having proven her deep and abiding love for the son whose mind she is endeavoring to form, Barber is not the ancestress of Virginia Woolf's spectral Angel in the House, who "was so constituted that she never had a mind or a wish of her own, but preferred to sympathize always with the minds and wishes of others" (245). Just as she can write literature for both children and adults, Barber can sympathize with the minds and wishes of others and still have a mind of her own.

Con Barber, teased as a schoolboy about his inelegant Latin, was to have a great deal more Latin in his education, and he would have had to master it in studying medicine. His mother's doting seems to have paid off, her early maternal pride justified. ${ }^{30}$ Elected a scholar of Trinity College, Dublin, in 1732, Con graduated with an $\mathrm{AB}$ in the spring of 1734. Eventually, as professor of materia medica and pharmacia, he was elected president of the Royal College of Physicians in Dublin three times, the first in 1754, a year before his mother died. In a 1775

\footnotetext{
${ }^{29}$ The conventional soft complaint that women were not taught Latin is interesting since, by 1727 , Constantia Grierson had edited Terence's Comediae and, in 1730, the work of Tacitus (Elias, "Manuscript" 43-44, 55-56).

${ }^{30}$ At times, Mary Barber and Hibernia are one: her outrage that Hibernia's "Sons in Science skill'd, / And yet her Posts by Strangers fill'd" (191) accomplishes this conflation. These material concerns reflect the shift Hilton describes with "the effervescent culture of mercantile capitalism creat[ing] a new kind of enterprise patrimony full of educational potential" (29). Irish nationalism, in keeping with Swift's position - and of the largely Protestant merchant class to which Barber belonged - is raised in such poems as the one explaining that her son "desires [her] to accept his first Prize of Learning, conferr'd on him by the University of Dublin" (189). Barber's tongue-incheek response in "A Letter for my Son to one of his Schoolfellows," in which the mother bewails her son's writing verse to please his schoolmaster (“"A fine Way of training a Shopkeeper's Son! / 'Twould better become him to teach you to dun"' [78]) plays with satisfaction with class in ways belied by the emphasis on Con's success and his own verses to his mother at the end of the book.
} 
retrospective poem, John Gilborne, MD, wrote approvingly of Dr. Barber's knowing "How to prepare, preserve, compound and chuse / All indications curative fulfill." 31 The upward mobility that Con achieved was evidently due less to his merchant father than to the ambition and encouragement of that merchant's wife.

After the topic of her son and that of gratitude to friends, Barber's Poems on Several Occasions entertains a preoccupation with health itself: gout and arthritis, headache and toothache both hinder and inspire her work. The final poem in her collection, "To a Lady, who commanded me to give an Account in Verse, how I succeeded in my Subscription," combines two persistent sources of worry: health and publication. In this epistolary poem to a friend recounting a number of unsympathetic responses, the speaker ventriloquizes a gossipy naysayer:

Besides, I oft have heard it hinted, Her Poems never will be printed: Her Sickness is a Feint, no Doubt, To keep her Book from coming out. (278-79)

Following hard upon Constantine's own poems praising his mother, this proof-isin-the pudding response is a satisfying close to the collection, and by preceding this last poem with Con's, she provides the answer to Sabina's rhetorical question: "What! - must our Sons be form'd by Rhyme? / A fine Way to employ one's Time!" (277). Obviously Con Barber has been in part "form'd by Rhyme" and both he and his mothers have employed their time well.

Furthermore, considering the tradition of imagining a book as a child and the presence of sickness (indicated by the possible play between feint and faint), something interesting happens here. As noted above, Barber was ill much of the time during which she was writing and certainly while soliciting subscriptions for her collection. A willing spirit combined with weakness of flesh such as gout and severe headaches is a perfectly reasonable condition to attend upon the coming out of both books and babies for this artist-mother. For Mary Barber, her book, like Con, is here: out and thriving. In this volume, she has, as Dr. Constantine Barber would later do with tonics and powders, "prepared" and "preserved" her poems and, to some extent at the same time, her offspring. So, although the traditional Mrs. Barber would not have asked for "the privilege for my masculine part the poet in me" in so many words, her unsound body and sound mind have

${ }^{31}$ The Medical Review: A Poem (qtd. in Kirkpatrick 116). 
together formed a masculine part based on maternal traditions: her son, both in poetry and in fact.

\section{Conclusion: Generations}

Mary Barber wrote for a variety of purposes and readers: to please Jonathan Swift, to praise and thank her friends, to celebrate occasions, and to pay homage to the writings of others. She wrote to punish those who had failed in loyalty. She wrote for money. She also wrote-first, as she tells us - for children. It is important to see this poet-mother of the 1730s as innovative as well: she was a forerunner to those who, decades later, spoke to and on behalf of those whose voices were not often heard.

The bluestocking circles largely responsible for and responsive to such educational movements as Sunday school campaigns (as well as anti-slavery poetry that emphasized childhood and motherhood in its appeals for abolition) are critically situated in the later eighteenth century. ${ }^{32}$ These women, as Lissa Paul demonstrates, "were engaged in the kinds of maternal teaching practices directed toward encouraging children to become thinking and knowing adults" (96). I do not believe that, for all her humility, when Barber intertwined her voice with that of her son, she thought of weakening or diminishing her own authority; she strove for a double liberation.

Subscription lists tend to be comprised of adults, some of whom, like Swift in the case of Mary Barber's Poems, subscribed for several copies. Although Grenby argues "we cannot avoid the suspicions that many late seventeenth- and early eighteenth-century children, however privileged in other respects, did not encounter the writing that was being published specifically for them" (94), he also makes an important point that "the rise of children's literature depended heavily on the gift economy" (192). Such an economy dovetailed with that of subscription publication. John Newbery in the 1740s "saw that he would have to attract adults before children" (Pickering 222) to sell his own categorically children's books. Barber's verse is a reminder that, among the reasons we find so little "children's literature" prior to the 1740 s, we might identify a bias against poetry in favor of fictional prose. ${ }^{33}$ Another reason is our tendency to see children's literature as marginalized by rather than - as it has frequently been - embedded in the literature of adults, both before and after John Newbery's successfully marketed series. Certainly, Barber's collection reflects Ruth K. MacDonald's observation

\footnotetext{
${ }^{32}$ See Myers.

${ }^{33}$ Scholars are working diligently to rectify this lacuna. See, for example, Coats.
} 
that "Children's books . . can illuminate how children and adults acted towards each other, and what adults, and parents in particular, thought children needed and wanted" (1). In Barber's preface, where she explains she has written "chiefly to form the Minds of my Children" (xvii), that qualifier chiefly is significant. She is not prevaricating; she is prioritizing. Nor does ventriloquizing her eldest son suggest appropriation solely for her own empowerment: both the boy and the woman are empowered by the poems and the several occasions that are the story of this book.

What was written “for" Mary Barber's son, for herself, and for her diverse readership that includes women and children and men, is not simple. Even with so much scholarship exploring children's cultures, we remain suspicious of what does not look to us like what we have told ourselves about children's literature. Jack Zipes pointed out that "the concept of a children's literature is . . imaginary, referring to what specific groups composed largely of adults construct as their referential system" (40). This being the case, the various poems referencing Constantine Barber in Mary Barber's verse collection - using him, defending him, instructing him, and imagining him - must also be read as (among other things) belonging to the tradition of children's literature to which the poet claimed they belonged. 


\section{Works Cited}

Barber, Mary. Poems on Several Occasions. London: Rivington, 1734.

Barnett, Louise. Jonathan Swift in the Company of Women. k: Oxford UP, 2007.

Behn, Aphra. The Works of Aphra Behn. Edited by Janet Todd, vol. 7, Pickering \& Chatto, 1996. 7

Blain, Virginia, Patricia Clements, and Isobel Grundy. The Feminist Companion to Literature in English: Women Writers from the Middle Ages to the Present. Batsford, 1990.

Brown, Laura. Fables of Modernity: Literature and Culture in the English Eighteenth Century. : Cornell UP, 2001.

Budd, Adam. "'Merit in Distress': The Troubled Success of Mary Barber." Review of English Studies, vol. 53, no. 210, 2002, pp. 204-27.

Coats, Karen. "The Meaning of Children's Poetry: A Cognitive Approach." International Research in Children's Literature, vol. 6, no. 2, 2013, pp. 127 142.

Connery, Brian A., editor. Representations of Swift. University of Delaware Press, 2002.

Darton, F. J. Harvey. Children's Books in England: Five Centuries of Social Life. 1932. Cambridge UP, 2011.

Delany, Mary. The Autobiography and Correspondence of Mary Granville, Mrs. Delany. Edited by Lady Llanover, London: R. Bentley, 1861. 3 vols. Google Books.

Demers, Patricia, editor. From Instruction to Delight: An Anthology of Children's Literature to 1850. 2nd ed., Oxford UP, 2004.

Doody, Margaret Anne. "Swift among the Women." Critical Essays on Jonathan Swift, Edited by Frank Palmeri, G. K. Hall, 1993, pp. 13-37. 
Elias, A. C., Jr. "Editing Minor Writers: The Case of Laetitia Pilkington and Mary Barber." 1650-1850: Ideas, Aesthetics, and Inquiries in the Early Modern Era, vol. 3, 1997, pp. 129-47.

—_. "A Manuscript Book of Constantia Grierson's." Swift Studies, vol. 2, 1987, pp. 33-56.

Ezell, Margaret J. M. Writing Women's Literary History. Johns Hopkins U P, 1993.

Fanning, Christopher. "The Voices of the Dependent Poet: The Case of Mary Barber." Women's Writing, vol. 8, no. 1, 2001, pp. 81-97.

Folkenflik, Robert. "The Rupert Barber Portraits of Jonathan Swift." Representations of Swift, Edited by Brian A. Connery, University of Delaware Press, 2002, pp. 117-49.

Gamache, Robert N. Swift: Peculiar Supporter of Female Writers. Master's thesis, University of South Florida, 2009, http://scholarcommons. usf.edu/etd/1979.

Gilbert, Sandra M., and Susan Gubar. The Norton Anthology of Literature by Women: The Tradition in English. 3rd ed., Norton, 2007.

Grenby, M. O. The Child Reader, 1700-1840. Cambridge UP, 2011.

Hilton, Mary. Women and the Shaping of the Nation's Young: Education and Public Doctrine in Britain, 1750-1850. Ashgate, 2007.

Kirkpatrick, T. Percy C. History of the Medical Teaching in Trinity College, Dublin and of the School of Physic in Ireland. Dublin, Hanna and Neale, 1912. Internet Archive.

Lavoie, Chantel. "Tristram Shandy, Boyhood, and Breeching." EighteenthCentury Fiction, vol. 28, no. 1, 2015, pp. 85-107.

Locke, John. Some Thoughts Concerning Education. Educational Writings of John Locke, Edited by John William Adamson, Cambridge UP, 1922, pp. 2179.

Lonsdale, Roger. Eighteenth-Century Women Poets. Oxford UP, 1989.

Love, Harold. Attributing Authorship: An Introduction. Cambridge UP, 2002. 
MacDonald, Ruth K. Literature for Children in England and America from 1646 to 1774. Whitston Publishing, 1982.

Myers, Mitzi. "Impeccable Governesses, Rational Dames, and Moral Mothers: Mary Wollstonecraft and the Female Tradition in Georgian Children's Books." Children's Literature, vol. 14, 1986, pp. 31-59.

Nodelman, Perry. “Children's Literature as Women's Writing” Children's Literature Association Quarterly 13, no. 1, 1988, pp. 31-34.

O’Malley, Andrew. Children's Literature, Popular Culture, and Robinson Crusoe. Palgrave-Macmillan, 2012.

Orlando: Women's Writing in the British Isles from the Beginnings to the Present, edited by Susan Brown, Patricia Clements, and Isobel Grundy, Cambridge UP Online, 2006, http://orlando.cambridge.org.

Palmeri, Frank, editor. Critical Essays on Jonathan Swift. G. K. Hall, 1993.

Patterson, Annabel. Fables of Power: Aesopian Writing and Political History. Duke UP, 1991.

Paul, Lissa. The Children's Book Business: Lessons from the Long Eighteenth Century. Routledge, 2011.

Pickering, Samuel F., Jr. John Locke and Children's Books in Eighteenth-Century England. University of Tennessee Press, 1981.

Pilkington, Laetitia. Memoirs of Mrs. Laetitia Pilkington, edited by A. C. Elias, Jr., University of Georgia Press, 1997.

Poems by Eminent Ladies, edited by George Colman and Bonnell Thornton. London: 1755.

Prescott, Sarah. Women, Authorship and Literary Culture, 1690-1740. Palgrave Macmillan, 2003.

Salvaggio, Ruth. "Swift and Psychoanalysis, Language and Woman." Women's Studies: An Interdisciplinary Journal, vol. 15, no. 4, 1988, pp. 417-34.

Staves, Susan. A Literary History of Women's Writing in Britain, 1660-1789. Cambridge, Cambridge UP, 2006. 
Stewart, Wendy. "The Poetical Trade of Favours: Swift, Mary Barber, and the Counterfeit Letters." Lumen, vol. 18, 1999, pp. 155-74.

Swift, Jonathan. Correspondence of Jonathan Swift, edited by Harold Herbert Williams, rev. ed., Clarendon Press, 1963-65.

—. Gulliver's Travels, edited by Claude Rawson, Oxford UP, 2005.

—_. "Letter to John Boyle, Earl of Orrery." In Barber, pp. iii-viii.

Thomas, P. L. "Expanding the Feminist Critical Lens: Using Children's Literature as a Means for Analyzing Women's Literature." English Record, vol. 57, no. 2, 2007, pp. 41-47.

Tribunella, Eric. "Boyhood." Keywords for Children's Literature, edited by Philip Nel and Lissa Paul, New York UP, 2011, pp. 21-25.

Tucker, Bernard, editor. The Poetry of Mary Barber ?1690-1757. Edwin Mellen Press, 1992.

Woolf, Virginia. "Professions for Women.” In Gilbert and Gubar, pp. 244-47.

Zipes, Jack. Sticks and Stones: The Troublesome Success of Children's Literature from Slovenly Peter to Harry Potter. Routledge, 2002. 